\title{
Gender Perspectives in Namibia's Communal Land: Exploring Women's Hindrances to Equitable Land Ownership
}

Journal of Asian and African Studies

(C) The Author(s) 2021

Article reuse guidelines: sagepub.com/journals-permissions DOI: 10.1 I77/002190962। I020486 journals.sagepub.com/home/jas

@SAGE

\section{Paulus Mwetulundila}

University of Namibia, Namibia

\begin{abstract}
Rural communities depend on land for socio-economic livelihoods. However, owning land remains a critical challenge in post-independence Namibia for women, despite institutionalised laws and policies designed to redress gender inequalities. This paper discourses on the hindrances to equitable communal land ownership in nine regions among women aged 18-60years. Findings reveal a high perception among women themselves that women should own land in communal areas. The study concludes that the struggle for equitable land distribution is far from being over, despite various government interventions to address the status quo, and hence recommends the overhaul of existing legal frameworks.
\end{abstract}

\section{Keywords}

Women, land, gender, inequality, communal

\section{Introduction}

The equitable distribution of resources to both genders has been identified as a global priority. The fifth sustainable development goal (SDG5) aims at achieving gender equality and empowering all women and girls (United Nations Development Programme, 2015). Land rights in Africa, just like elsewhere, remain a stronghold of male power and privilege, leaving women in a marginalised position in society. Since land is a fundamental resource for improving living conditions and economic empowerment, the lack of land rights for women undermines efforts to promote gender equity and equality within a patriarchal society (Kameri-Mbote, 2013). More than half of rural employment in Sub-Saharan Africa consists of self-employed farmers; many of these are women, who generally own less and low quality land (Adeniyi, 2010). These persistent inequalities that hinder women's equal land ownership are aftermaths of gender division of labour characterised by patriarchy: a social system in which males hold primary power and predominate in political leadership roles, social privileges and control properties embedded in different cultures.

Scholars who perused gender inequality in Namibia's land provision argued that inequality existed long ago during pre-colonial period. During that time, the economy was purely agrarian, 
based on the collective utilisation of resources. A clear manifestation of gender division of labour erupted when females became the primary source of labour and fertility that ensured future labour supply (Jauch et al., 2011). Society had mutual ownership of significant productive assets, which ensured a fair distribution of wealth within the community. At the onset, important necessities such as land and livestock were possessions of the community groups and individuals did not have the right to claim ownership of such resources. Subsquently inequalities in terms of gender erupted when men began controlling women's labour, controlling social surpluses produced by female labour and controlling women's sexuality and fertility. Although the land was a collective possession, the system favoured men, who alone had the privilege of land ownership, over women. Adult males were beneficiaries of land from the chiefs and had control over key productive resources (Jauch et al., 2011).

Furthermore, Edwards and Cupido (2011) argued that this shaped what they termed the trajectory of gender inequalities that persists in the country up to the present day, in a society characterised by current and historic unequal power relations between women and men, whereby women are systematically disadvantaged and oppressed. Werner (2008) argued that the right of women to own land, and more specifically to inherit land in their own right, is an increasingly topical issue. Widows have been evicted from the land they had cultivated for years though there is no reliable empirical evidence suggesting how widespread this practice is.

Since the genesis of the democratic dispensation, the Namibian government has developed policies that have focused on gender equality. The National Land Policy was instituted under the custodianship of the Ministry of Land Reform, previously called the Ministry of Land and Resettlement, and aimed at national reconciliation, constitutionality and nation building, targeting the problems of dispossession, discrimination and inequitable distribution of land that characterised the country's pre-independence era (Ministry of Land and Resettlement, 1998).

Although Werner (2008) noted positive outcomes of the National Land Policy, that there was a considerable decrease of evictions over the years and a promotion of gender equality in land distribution, there is such a considerable imbalance inherited from a century of colonialism that it has been too large to overcome even after two decades of independence. Hence, there has been a constant need to find creative means by which the lives of the rural poor living in the communal areas can be improved. One such way was to introduce land registration in the communal areas for the purpose of tenure security for the people holding land rights in those areas. The registration of such rights is made possible by the Act of Parliament known as the Communal Land Reform Act, Act No. 5 of 2002. Thus this paper aims to explore the social impediments to this and to what extent they limit women's equal rights to land ownership as opposed to their male counterparts. It further seeks to discover the level of awareness among women about the legal frameworks institutionalised by the government in a quest to redress the imbalances that existed in the provision of communal land ownership in post-independence Namibia.

\section{Review of literature}

Gender inequality in Namibia is culturally embedded and long existed in pre-colonial communities. In pre-colonial Namibia, agricultural production was subsistence-based, and there was a gender-based division of labour whereby hunting was the preserve of men whilst child rearing, preparation of food and cultivation of crops were women's obligations (Jauch et al., 2011). Hubbard and Solomon (n.d.) posited that it is difficult to generalise Namibia's pre-colonial gender relations due to the multiplicity of ethnic groups. Nevertheless, it can be said that in many communities, there was a sex-based division of labour in which women played an important if unequal role in both production and reproduction. Hubbard and Solomon pinpointed, for example, how in Herero 
pastoral communities, the barring of women from hunting and stock raising limited their role in production and confined them mainly to child rearing and tasks around the house. In the mixedfarming Owambo communities, women were also excluded from animal husbandry, but were involved in crop production and were responsible for household reproductive roles. Nonetheless, it was mainly the men who decided when and how crops and livestock would be used. The harvest from the wife's plot was consumed by the household while that from the husband's plot was disposed of by him as surplus. Thus, even though women did have a role in production, their economic involvement was undermined.

Hubbard and Solomon (n.d.) further argued that men generally held the positions of influence in pre-colonial communities, although there were some exceptions, and men usually had larger economic decision-making power within extended family units. Lobola (bride-price) also immensely contributed to the relatively inferior position of women; men often believed that they could exercise total control and power over their wives since they had 'paid' for them. While ensuring sufficient labour for the household and arguably reducing the workload of individual women, polygamy intensified sexual inequality by tying a woman's status to her rank as a wife. While women's pre-colonial position was later analysed as conferring an inferior status upon them in most communities, it has been asserted that notions of gender equality or inequality were simply non-existent during this early period, and that men and women were perceived as inhabiting and controlling different and complementary spheres (Hubbard and Solomon, n.d.).

According to Akawa (2014), although the inequalities had existed before, they intensified with the arrival of the missionaries and the inception of colonialism. Missionaries and colonialism collaborated with the local elites by subordinating women for their own benefit. Akawa (2014) further noted that customary laws were created and came into effect and that through these collaborative laws, patriarchy manifested unopposed and subsequently created inequalities between men and women. During this period, the missionary influence was undermining traditional ideology and religion, and holding up submission and subordination as model behaviour for women - while also providing useful educational opportunities for women in some parts of the country. In the white settler communities, women generally remained in the private domain of the home while the realm of public activity was completely male-dominated. Colonial rule brought new legal, social and economic bases for women's subordination. Gender dynamics were profoundly affected by the system of migrant labour, which was imposed by the colonial administration in 1925, primarily to ensure a supply of cheap labour in the country's mines. A range of influx control laws ensured that workers' families remained in rural 'native reserves', which became in effect dumping grounds for women, children, the aged and the sick (Hubbard and Solomon, n.d.). In the same vein, Likuwa and Shiweda (2017) asserted that male migration during the contract labour system affected the Owambo communities. There were no male labourers for the household agricultural activities and women were left alone to deal with family activities which included the care of domestic animals and subsistence farming. These divisions had several implications for the sustainability of the household's livelihood, particularly food security. The impact was less in Kavango compared to the Owambo because the latter's homesteads for married couples were usually built within the boundaries of the parents' homesteads where family members were usually responsible for the welfare of others. During the absence of a husband, there were usually other adult males left within those homesteads to help with agricultural work and other household activities.

Since it is widely acknowledged that the existing gender inequality is the aftermath of gender division of labour present since the pre-colonial and retained during the post-colonial era, which consequently accorded an inferior status to women, the Namibian government, like many other governments across the globe, put in place various laws and policies designed to redress inequalities in terms of gender. The Namibian constitution (which employs a gender-neutral formulation of 
'he and she' throughout) explicitly forbids discrimination on the grounds of sex and authorises the establishment of affirmative action "with regard to the fact that women in Namibia have traditionally suffered special discrimination and that they need to be encouraged and enabled to play a full, equal and effective role in the political, social, economic and cultural life of the nation' (Hubbard and Solomon, n.d.). One of the earliest strides towards gender equality advocacy in Namibia was the Department of Women Affairs (DWA) which was established as a gender focal point in the government under the office of the President shortly after independence to play the co-ordinating role in respect of gender subjects (Republic of Namibia, 1995). Therefore, through the DWA, in 1992 the country ratified the UN Convention on the Elimination of All Forms of Discrimination against Women (CEDAW) that advocates for member states to act swiftly against discriminatory practices based on gender (Ruppel, 2008). Thus, the mid-1990s saw government interventions in addressing gender inequalities that had been created during the pre-colonial era and retained during the colonial and post-colonial eras (Republic of Namibia, 1995). A milestone was achieved when the government managed to establish the independent Ministry of Women Affairs and Child Welfare (MWACW). The major roles of MWACW have been to provide services and coordination to the public on concerns of gender, children and development. Its mission is to ensure gender equality and socio-economic development of women and men and the well-being of the children.

Subsequently, in 1997, the government also adopted the National Gender Policy, which marked an important step toward the attainment of gender equality in the country. The policy provided a framework to guide the implementation of programmes aimed at meeting the expectations of the Namibian people, especially women's attainment of fundamental freedom and equality with their male counterparts with regard to participation in all developmental programmes and nation-building efforts (Ministry of Gender Equality and Child Welfare [MGECW], 2010). The National Land Policy was also effected, aiming at national reconciliation, constitutionality and nation building, and targeting the problems of dispossession, discrimination and inequitable distribution of land that characterised the country's pre-independence era. The government also passed an Act of Parliament known as the Communal Land Reform Act, Act No. 5 of 2002 to ease the process of land rights for all. The Communal Land Reform Act grants women equal rights when they apply for communal land, and protects the surviving spouse of the deceased holder of a customary land right by giving the surviving spouse, who is a woman in most cases, the right to apply to the chief or traditional authority to reallocate that right in his/her name. According to section 4(1)(d) of this Act, communal land boards, who are responsible for the ratification of land rights, are obliged to include at least four women (Ambunda and de Klerk, 2008). The guide to the Communal Land Reform Act stipulates that two women must farm in the board's area and the other two must have experience relevant to the functions of a board, which implies that they do not necessarily have to be headwomen (Malan, 2003). This means that women are given an active role in decision making regarding land allocation in communal areas. Overall, after independence, various legal reforms were carried out in pursuit of gender equality in terms of economic and social justice for all. Discriminative cultural practices, patriarchal ideologies and historical imbalances have been the primary focus under the new legal reforms.

\section{Rural women's livelihood in Namibia}

According to the 2011 Population and Housing Census, women constitute $43.8 \%$ of heads of households in Namibia. The regions that are reported to have the highest number of female-headed households in the country are Ohangwen (56.5 percent), Omusati (55.3 percent) and Oshana (53.7 percent) (Namibia Statistic Agency, 2012). The livelihoods in all studied regions consisted of several different income streams. Subsistence farming was the main source of income for many 
households. The statistics testify that there is growing evidence of increased responsibilities of women within rural livelihoods. Women have to fight hunger and combat poverty, and to do this they need land at their utmost disposal.

\section{Women's inferiority and limited land right}

Vulnerability comes in many forms. Some people, particularly women, find themselves in vulnerable situations in which they either were supposed to inherit and could not obtain those rights or have been chased from their land for unlawful reasons. Therefore, all laws apply equally to all Namibians. For communal land, any person belonging to a traditional community has equal rights to communal land. The traditional authority and communal land boards are given the power to uphold the constitution and all other laws in order to protect the rights of the vulnerable (Ministry of Land and Resettlement, n.d.). Some groups of people, however, are more vulnerable and therefore need protection. This protection is guaranteed through Article 10 of the Constitution of Namibia, which emphasises that all persons are equal before the law. No person may be discriminated against on the grounds of sex, race, colour, ethnic origin, religion, creed or social or economic status (Constitution of Namibia, 1990). However, despite the guarantees enshrined under the enacted laws, women continue to fall prey to unequal land access and ownership in Namibia.

A baseline study (Shapi et al., 2017) reveals that only 15 percent of women in the Ohangwena, Omusati, Oshana and Oshikoto regions gained land through applications to the traditional authorities and a further 14.8 percent did not get the land they applied for. There is an uncertainty in the modus operandi of the process for allocation of communal land as it is characterised by undemocratic acts. In these regions, village headman have discretion to reduce the size of land allocated to women and then allocate it to other people. Shapi et al. (2017) also further noted that 16 percent of widows had to pay a fee (ombadu yekaya) to the headman to occupy land accessed through their departed husbands. Women are also not adequately informed about their land rights and this is the current status quo despite various interventions from the government to address the existing disparities.

In Namibia, the land is governed by different nested and often contradictory laws and legal provisions. This legal pluralism creates complexities in land reforms and administrations as well as discrepancies between statutory and customary law. These need to be addressed if women's rights to land are to be protected and access improved. The statutory law had made clear provision for gender equity in land distribution, which is not fully entertained under the customary law. The Communal Land Reform Act states that women have the same rights to land as men, whether married or unmarried. A single woman can apply for a land right just as a single man may. Traditionally, women could not get land rights and, in instances where they could get land, they may have had to get it through their husbands or other male relatives. To proactively meet its intended objectives, the Communal Land Right Act makes provision for: the allocation of rights in respect of communal land; the establishment of communal land boards; the powers of chiefs and traditional authorities and boards in relation to communal land; and other incidental matters (Ministry of Land and Resettlement, n.d.).

The state further regulates how communal land can be inherited as follows: whether married under customary law or in a civil marriage, once a spouse dies the land automatically reverts to the surviving spouse. No traditional authority may take land from a widow when her husband dies. Furthermore, no widow can be forced to pay anything to the traditional authority or headman/ woman for inheriting her late husband's land right (Ministry of Land and Resettlement, n.d.). However, despite the institutionalised legal framework, women, especially widows, have endured threats of evictions from the land after the death of their husbands. 


\section{Theoretical framework}

This paper is mainly grounded on liberal feminist theory. Giddens (2001), as cited in Samkange (2015: 1173), defines liberal theory as a 'feminist theory that believes gender inequality is produced by reduced access for women and girls to civil rights and allocation of social resources such as education and employment'. It can be noted that in this definition liberal feminist theory acknowledges the existence of disparities in society that are gender related. According to Enyew and Mihrete (2018), this situation is chiefly entrenched by the socially constructed ideology of patriarchy that promotes inequality between the two sexes. As cited in Enyew and Mihrete (2018), Maynard (1995) posited that liberal feminism concentrates on individual rights and the concepts of equality, justice and equal opportunities, where legal and social policy changes are seen as enablers for promoting gender equality.

Theoretically, liberal feminism claims that gender differences are not based on biology, and therefore women and men are not all that different. If women and men are not different, then they should not be treated differently under the law. Women should have the same rights as men and the same educational and work opportunities, which had never been the case. Thus according to Szapuová (2006), John Stuart Mill - a liberal feminist - argues that any gap in intellectual achievement between men and women can be explained by the better education and privileged social position which men enjoy. Szapuová (2006) further argues that Mill can be considered one of the very few exceptions to the androcentric character of Western philosophy. He posits that Mill stands out from a long tradition that tended more to devalue and marginalise women and subjects concerning relations between the sexes, or to keep silent about them, than to develop philosophical ideas and explanations regarding women's subordination and consider gender issues based on the principle of the equality of women and men. Liberal feminists, on this account, regard the goal of feminism as the achievement of formal equality under the law.

Tong (2009) as cited in Enyew and Mihrete (2018) argued that welfare liberals advocate for state interference to make adjustments in order to make a level playing field for everyone and provide basic requirements. The classical liberals assert that the state's role should be protecting civil rights, providing everyone with equal opportunity and freedom to enter into the free market. In Namibia, there has been lobbying for gender equity in different spheres of life since the country's independence in 1990. Such lobbying has significantly contributed to important legislation that has backed reforms in different areas including women's representation in leadership positions. The post-colonial government of Namibia had to abolish different forms of discrimination. The government abolished discrimination based on gender, race, class, religion or any other form of discrimination. In ensuring the abolishment of discrimination on the ground of gender, the Constitution of the Republic of Namibia, Article 10 sub-articles (1) and (2), guarantees the equality of all persons before the law, and prohibits discrimination against any person on the grounds of sex, race, colour, ethnic origin, religion, creed or social or economic status (Constitution of Namibia, 1990). This was further enhanced by the passing of the Affirmative Action Act 29 of 1998 and the National Gender Policy of 2010-2020. This legislation fostered fair employment practices with regard to recruitment, selection, appointment, promotion and equitable remuneration of previously disadvantaged persons. More specifically, previously disadvantaged persons such as women and persons with disabilities were referred to as the designated group. Such interventions allowed women to enter the work force in various positions and industries that have been male domains, but not at management level (Employment Equity Commission, 2002).

The enactment of such laws and designing such policies inter alia can be attributed to liberal feminism within the political structures and lobby groups such as the Women's Action Development (WAD). WAD is a Namibian-based non-profit making organisation and has been operational since 
1994. Although WAD has progressed to empower both women and men on an equal basis, the original purpose of its establishment was, and still is, to work towards the upliftment of the living standards of impoverished rural women in particular, by imparting knowledge and skills that would enable them to effectively run their own income-generating projects, or to find jobs (De Klerk, n.d.). However, it is imperative to trace the effectiveness and ineffectiveness of the organisation's interventions targeted at improving the livelihood of rural women, since its inception, which will inform similar current and future programmes.

Although Namibia is classified by the World Bank as an upper-middle-income country with an estimated annual Gross Domestic Product (GDP) per capita of US\$5293 (National Planning Commission, 2012), wealth is unequally distributed. The majority of poor people are women who reside in the rural areas of the country. According to the National Planning Commission (2015), 15 of the country's poorest constituencies are engaged in the subsistence communal farming sector. Women also make up a high number of communal inhabitants and endure marginalisation in land access, ownership and control of land, a phenomenon that has a long history from pre-colonial and colonial times, right up to the present. Gender inequalities in land access, ownership and control, as well as inequalities in accessing services and inputs to make land more productive, persist despite non-discrimination clauses in our constitution and legal frameworks. As the statistics show, women are still discriminated against in the allocation of communal land, resettlement schemes and freehold land. Like Ethiopia, as noted by Enyew and Mihrete (2018), Namibia is also an androcentric culture that keeps women at the periphery, using religion and culture as excuses. These reasons have for a long time been augmented in legal frameworks and enactments that maintain androcentric society and women's relegation.

In Namibia, many governmental and non-governmental organisations are working to promote women's rights and empowerment in particular and gender equality at large through legal frameworks. These attempts are in line with liberal feminism in that securing gender equality is gradually reducing stereotypes and prejudices as well as customary and other practices that fuel gender discrimination. Hence, the government passed the Communal Land Reform Act, Act No. 5 of 2002 to ease the process of land rights for all. This study, within the liberal feminist frameworks institutionalised by the government, investigates women's hindrances to equitable land ownership.

\section{Methodology and data analysis}

This study is an extract of raw secondary data collected from the larger study conducted by the Multidisciplinary Research Centre of the University of Namibia titled 'Women's Land Use, Ownership and Rights in Namibia'. The main study employed a mixed methods approach to collect information through interviews on social and cultural factors impacting women's rights to communal land ownership in nine regions of the country, namely: Kavango West, Kavango East, Zambezi, Kunene, Otjozondjupa, Erongo, Omaheke, Hardap and //Karas. A sample of 1000 women aged 18-60 years were interviewed using open- and closed-ended questions. Traditional leaders, land board members and national councillors were also interviewed as key informants in divulging roles of their respective bodies in terms of land distribution. Of interest to this study, the main study focused on themes that collected information pertaining to women's hindrances to equitable land ownership. These include, inter alia: Can women own land? How can women obtain land of their own? How do people in your village/community feel about you as a woman having communal land of your own? Have you ever had problems regarding your communal land because you are women? If yes, what were the problems? Do you know about the Communal Land Reform Act, a law that deals with communal land use and land rights which the 
Table I. Perception of whether women can own communal land.

Perception of whether women can own communal land

Percentage (\%)

It depends on their marital status

12.9

Any woman can own communal land of her own

76.6

No, women cannot own communal land but they can farm on communal land that

6.7

belongs to a male relative

Other/specify

1.6

No responses

2.2

Total

100.0

Source: Author's own.

government passed in 2002? Who informed you/from whom did you hear about the new law with regard to women's rights?

All completed questionnaires were numbered for easy identification and reference and a data entry template was designed in Statistical Package for Social Science (SPSS); data was then entered by data entry clerks. SPSS generated basic and descriptive results presented in graphs and tables, while information from in-depth interviews was transcribed and organised into themes. ATLAS.ti was used to generate themes by grouping similar information under recurring themes. Literature analysis of existing information relating to the topic was used to enrich the discourse.

\section{Findings}

\section{Perception of women's ownership of communal land}

The study reveals a high (76. 6 percent) general perception among respondents that women should own land in communal areas. This increasing perception can be attributed possibly to the concept of gender mainstreaming, which has been one of the government's priorities in empowering women in different spheres. About 12.6 percent indicated that for women to obtain land, it entirely depends on their marital status. This implies that preferences are given to married women rather than single women. However, a mere 6.7 percent of women are reported as affirming that women cannot own communal land but they can farm on communal land that belongs to a male relative. Table 1 presents the different perceptions among women in relation to women's land ownership.

\section{Community perception of women's communal land ownership}

A total of 44 percent of women believe that there are still members of the general public who hold the conservative belief that women should not own land in their own right simply because they are women. This shows that there is an internalisation of oppression among women themselves and they accept it as a norm. A number of women (20 percent) narrated that women are ridiculed when embarking on obtaining land rights of their own. Different perceptions are illustrated in Table 2.

\section{Means of acquiring communal land}

Table 3 depicts various ways that women can acquire land of their own. This study shows that about 92 percent of women indicated that women in their community can obtain land via inheritance from their late parents. At the same time, 83.3 percent of them said it is possible to obtain the 
Table 2. Community perception on women's land ownership.

Community perception on women's land ownership

Percentage (\%)

People feel that I should not have land because I am a woman

44

People feel my land is so big because I am a woman

14

People ridiculed me for wanting land of my own

20

People feel that a married woman is greedy if she applies for her own land in addition to II that of her husband's

My husband's family feels that I should not have inherited the land

Total

100

Source: Author's own.

land from the traditional authority independently by applying or asking for permission to use the land. About 79.7 percent reported that they can inherit land of their late husbands, whilst 77.6 percent said they may inherit land of late relatives. About 70.6 percent of women claimed that land ownership in women's favour can also be acquired by having land from a relative (e.g. aunt, uncle) transferred into their name. Another means of communal land acquisition by women is through buying from traditional authorities, which accounted for 61.3 percent.

\section{Challenges encountered by women in communal land ownership}

Generally, there are multiple challenges faced by women, particularly, widows in owning land after the death of their late husbands. The study indicated that widows usually receive several threats that forcefully evict them from the land they co-owned. About 26 percent of the respondents reported that women endure the threat of being bewitched by their late husbands' families if they continued to stay on the land, whilst 22 percent reported the threat of eviction. Table 4 depicts several challenges that widows are more likely to encounter after the death of their late husbands.

\section{Lack of awareness of legal provisions}

Most countries in Africa have constitutions that ascribe equality between male and female. However, with land laws which are either gender-neutral or affirmative of women's land rights, the general public is usually not aware or conversant with such provisions. This is because once the land policies are adopted and land laws passed, there is no deliberate effort made by the state to sensitise the general public on what these documents say about peoples' land rights in general and women's land rights in particular (Odeny, 2013).

Although the Communal Land Reform Act is advocating for women's equal rights to land ownership as male counterparts, whether married or unmarried, a high number of women (31 percent) in communal areas are not familiar with the Act. Only 5.6 percent of women affirmed that they are acquainted with the Act, while 6 percent know a little about it. A total of 45 percent of respondents could not ascertain whether they are well conversant, know a little or are not familiar at all. Those that have some familiarity with the Act have given the source of their information as illustrated in Figure 1. Headmen (48 percent) are the major sources of the information in their respective communities, followed by the media (29 percent). Media encompasses radios, newspapers and other modern forms of information transmission such as social media. However, the radio plays a significant role in transmitting information across rural communities. Newspapers would have less impact 
Table 3. How can women obtain communal land of their own?

\begin{tabular}{|c|c|c|}
\hline Women's means of acquiring communal land & $N$ & $N(\%)$ \\
\hline \multicolumn{3}{|l|}{ Inherit the land of their late husband } \\
\hline Yes & 714 & 79.7 \\
\hline No & 182 & 20.3 \\
\hline Total & 896 & 100.0 \\
\hline \multicolumn{3}{|l|}{ Inherit the land of their late parents } \\
\hline Yes & 845 & 92.0 \\
\hline No & 73 & 8.0 \\
\hline Total & 918 & 100.0 \\
\hline \multicolumn{3}{|l|}{ Inherit the land of a late relative } \\
\hline Yes & 679 & 77.6 \\
\hline No & 196 & 22.4 \\
\hline Total & 875 & 100.0 \\
\hline \multicolumn{3}{|l|}{ Apply for land on their own } \\
\hline Yes & 767 & 83.3 \\
\hline No & 154 & 16.7 \\
\hline Total & 921 & 100.0 \\
\hline \multicolumn{3}{|c|}{ Having a relative's (e.g. aunt, uncle) land transferred into their name } \\
\hline Yes & 608 & 70.6 \\
\hline No & 253 & 29.4 \\
\hline Total & 861 & 100.0 \\
\hline \multicolumn{3}{|l|}{ Buy communal land } \\
\hline Yes & 532 & 61.3 \\
\hline No & 336 & 38.7 \\
\hline Total & 868 & 100.0 \\
\hline \multicolumn{3}{|l|}{ Other ways of obtaining land } \\
\hline Yes & 39 & 100.0 \\
\hline No & 0 & 0.0 \\
\hline Total & 39 & 100.0 \\
\hline
\end{tabular}

Source: Author's own.

Table 4. Problems faced by women as land owners.

Problems faced by women as land owners

Percentage (\%)

My late husband's family threatened to bewitch me if I continued to stay on the land 26

My late husband's family threatened to evict me if I continued to stay on the land 22

My late husband's family took my property and left me only with the land $\quad 15$

The communal land allocated to me by the headman/woman was not the land I applied for 8

The TA refused to approve my application because I am a married woman II

The headman refused to approve my application because I a single woman 18

$\begin{array}{ll}\text { Total } & 100\end{array}$

Source: Author's own. 


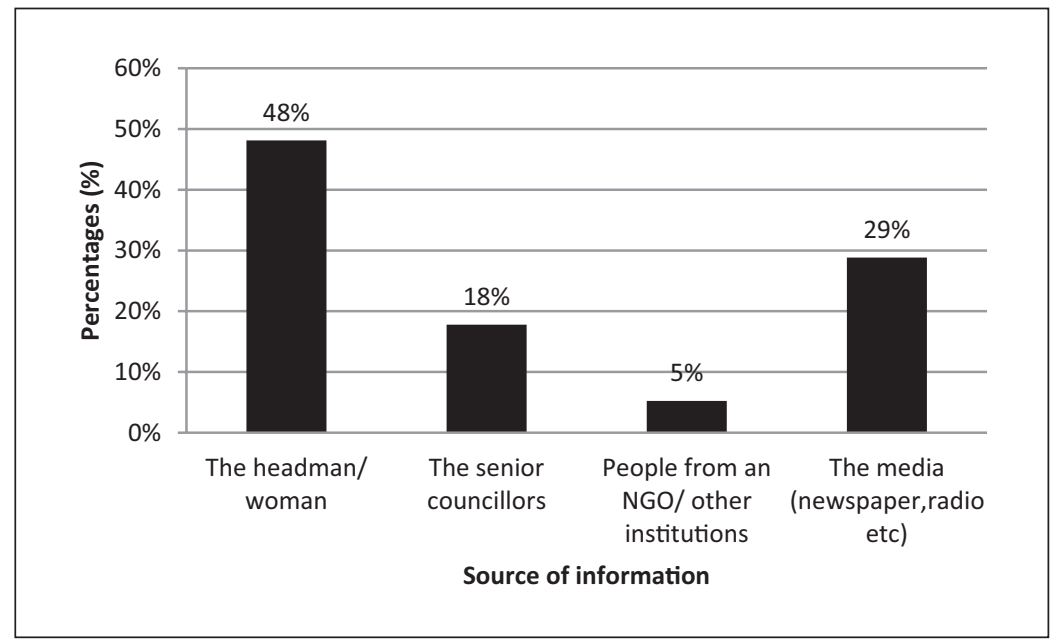

Figure I. Knowledge about Communal Land Reform Act.

Source: Author's own.

due to the remoteness of many communal areas and the low level of literacy within such locations. Non-governmental organisations appeared as the least prevalent sources of information.

\section{Women's impediments in benefitting from Communal Land Reform Act implementation}

The most significant reason why women have not benefitted from the Communal Land Reform Act is that women themselves believe that traditionally women are not supposed to own land. They were socialised into such norms and have internalised this oppressive belief that land does not belong to them. The level of awareness among rural women of the process of land acquisition is a stumbling block to women's land ownership. Figure 2 shows different perceived reasons why women did not benefit from the Communal Land Reform Act.

\section{Discussion}

\section{Interpretation of the findings}

The majority of people in the African continent and Namibia in particular attain their livelihood directly or indirectly from agriculture. Thus, the significance of women's land rights cannot be undermined because land is argued to be central to women's quest for equal rights. Because of the gender division of labour, women spend a lot of time working on the land and have limited ownership and land control rights. This exclusion is the root of the denial of women's social, economic and political autonomy that is vital for full membership in any given society. Land in any given community represents the vehicle through which women can move from the reproductive (private and non-work) realm to the productive (public and work) realm - a domain where women have been kept on the periphery.

Land is mainly in the hands of male household heads, with the assumption that the rights are held in trust for all in the household, which in reality is not the case at all. Despite the high 


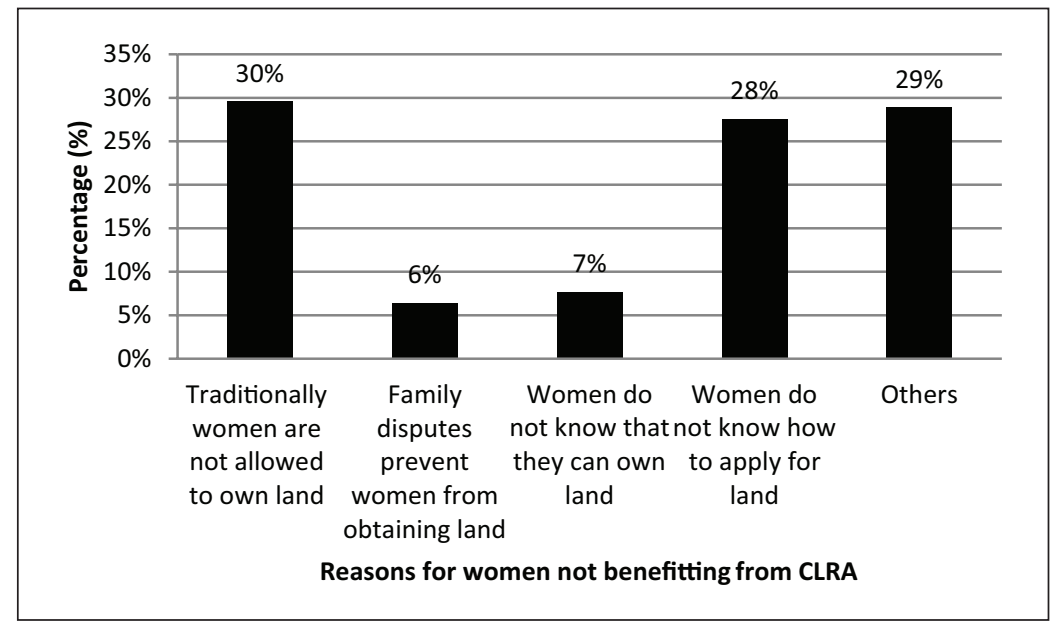

Figure 2. Reasons for not benefitting from Communal Land Reform Act implementation. Source: Author's own.

perception (76.6 percent) that women too can own land, in practice it remains difficult for many women to own land under customary law in Namibia. The community still hold a strong predominant belief that women should not own their land simply because they are women. This notion was affirmed by about 44 percent of the interviewed respondents. From all the perceived means of obtaining communal land, inheritance of land appears to be the easiest means for women, easier than obtaining land from the authorities. This is so because the land is already at the family's disposal, and it is further eased when women have the backing of older and reputable male relatives from their clans. Family is one of the social institutions where patriarchy is deeply embedded; males still hold dominant power and family members are more likely to conform to their instructions and decisions. Women are relegated to a subordinate position in accessing land, and Werner (2008) argued that there can be no doubt that women generally are subservient to men and derive their rights to land and resources largely through their relationships with men. This can be through either their husbands, fathers, uncles, brothers and sometimes sons. This type of land right always ends in squabbles when the relationship between the two turns sour.

To date, the literature has continuously depicted the importance of land, particularly to rural women who had been neglected in many developmental initiatives. According to the United Nations (2013), women's access to, use of and control over land and other productive resources are essential to ensuring their right to equality and to an adequate standard of living. These resources help to ensure that women are able to provide for their day-to-day needs, and those of their families, and to weather some of life's most difficult challenges. Women's access to land and other productive resources is integrally linked to discussions around global food security and sustainable economic development, as well as the pressing fight against the HIV epidemic and prevention of and responses to gender-based violence.

The study findings show that 30 percent of women in post-independence Namibia still believe that traditionally women are not allowed to own land, while 28 percent do not know the processes involved when applying for land. Thus, the issue of public awareness is very crucial to the rural masses. Women in the study indicated that most information about the Communal Land Reform Act emanated from their local headmen (48 percent), as illustrated in Figure 1. Although much of this information is more accessible on mass media, media accounts for 
29 percent as a source of information about the Communal Land Reform Act. This can be attributed to poor access to mass media such as social media within communal areas. Like many other countries, the media of post-independence Namibia serves as an important channel for conveying information, especially through digital media. However, this mode of information dissemination is restricted in remote areas where the level of illiteracy is high and where there is limited availability of facilities required for modern technologies. Information translates into knowledge and knowledge is power; if women are equipped with knowledge, they are more likely to ascend within their communities' hierarchical structures to partake in bodies such as land boards and to eventually lobby for other women. This will promote a quest to achieve a more egalitarian society where women will no longer be alienated from developmental initiatives but will be part of all the initial stages of developmental processes in their respective communities. It will be a prerequisite to achieving inclusive growth in terms of socio-economic development.

Land is also a social asset that is crucial for cultural identity, political power and participation in decision making. Women's equal access to land is a human rights issue. It also has multiple other benefits socially. Evidence shows that women's land rights reduce domestic violence and women who own land are more capable of exiting violent relationships (SIDA, n.d.). Furthermore, there is a clear demonstration that granting rights to women contributes to the national and household imperatives of family welfare, food security, empowerment, economic efficiency and poverty alleviation (Kameri-Mbote, 2013).

The right to land is regulated either by the formal legal system or through (traditional) customary law. Like many other African governments, the Namibian government should be commended for institutionalising gender-neutral policies and Acts that aim to address the inequalities created during the pre-colonial period and strengthened during the colonial era. However, it is little-known among women that there are legal frameworks advocating for equal ownership for both men and women and protecting the rights of those who already own land.

The enactment of such laws and the designing of such policies can be attributed to liberal feminism within the political structures. Theoretically, liberal feminism claims that gender differences are not based on biological make up, and therefore women and men are not all that different. If women and men are not different, then they should not be treated differently under the law. Women should have the same rights as men and the same educational and work opportunities (Lorber, n.d.).

To this end, it is arguable that the goals of liberal feminism in Namibia are embodied in various legislative frameworks. These include the Affirmative Action Act 29 of 1998, which seeks to improve gender equity in representation for marginalised groups in society including women and people with disabilities (Employment Equity Commission, 2015), and the National Gender Policy 2010-2020, which put measures in place to ensure equitable access to economic resources and opportunities, as well as social justice for both women and men (MGECW, 2010).

The government of Namibia also abolished discrimination based on gender, race, class, religion or any other form of discrimination. In ensuring the abolishment of discrimination on the ground of gender, the Constitution of the Republic of Namibia, Article 10 sub-articles (1) and (2) guarantees the equality of all persons before the law, and prohibits discrimination against any person on the grounds of sex, race, colour, ethnic origin, religion, creed or social or economic status (Government of the Republic of Namibia, 1990). 


\section{Recommendations}

The promotion of gender equality has been a guiding principle in policy development since the advent of Namibia's independence. However, gender inequalities prevail despite various government and non-governmental efforts. This study's findings might foster discussions on ways to improve gender equity in communal land distribution initiatives, particularly in the gendered communities. It recommends that there is a need for widespread government-led awareness campaigns in conjunction with rural communities' sensitisation on the Communal Land Reform Act.

Campaigners and activists for women's land rights should work with national and local government decision makers and should mobilise allies to deal with gatekeepers and those who are likely to resist change, particularly targeting the customary law. Remarkably, 48 percent of respondents indicated that their source of information pertaining to the Communal Land Reform Act is traditional authority, which is a male domain. This may demonstrate a mind shift within institutions where patriarchy is deeply embedded and that a number of men are informed about gender issues. More public engagements with men to enlighten them on equitable land distribution must be continuous. Other measures to challenge, engage and disarm the gatekeepers include civic education at national, local and community levels to raise awareness and build capacity so that women can contribute to both formal and traditional decision-making processes around land-related matters. The realisation of this can be through the expansion of women's representation within land administration bodies. This can be the appointment of women to traditional authorities as headwomen and to communal land boards. Affirmative action can also be useful in this regard to counteract the effect of discriminatory social norms and practices. Women's active involvement is required in traditional authorities and land boards in order to effect gender-neutral decisions. According to the Food and Agriculture Organisation (2010), this can be achieved if the gender dimension is considered in the early stages of a reform programme.

In a nutshell, there is a necessity to create more awareness among the individuals whom these legal frameworks are intended to benefit. For example, the Communal Land Reform Act stipulates that when the holder of a communal land right dies, the right goes back to the chief or traditional authority for reallocation - but a widow (or widower) has the right to reallocation of this communal land right if she (or he) wishes. If the land right is not taken up by the surviving spouse, it goes to a child of the deceased determined by the traditional leader to be entitled to the land (Hubbard, 2018). However, with little or no sensitisation in some incidences, women endure evictions from lands that were previously owned by their late husbands.

\section{Conclusion}

It is widely contested that women's right to land is a critical factor in social status, economic wellbeing and empowerment. It is also a social asset crucial for cultural identity, political power and participation in local decision-making processes. Moreover, land is a basic source of livelihood as it provides employment, it is the key agricultural input and it is a major determinant of women farmers' access to other productive resources and services. Women's rights to land are thus critical in the quest to create a more egalitarian society. However, despite all these significant roles that land plays in the livelihood for all, women lag behind because inequalities in land ownership in terms of gender prevail. Inequalities are enhanced by the patriarchal society's belief that traditional land should be owned by men and women should only work on it. Hence, neglecting women's rights to land ownership greatly affects them and places them in a more vulnerable state.

The Communal Land Reform Act and the National Land Policy were institutionalised in pursuance of gender equality in communal land acquisition with discriminative cultural practices, 
patriarchal ideologies and historical imbalances at the centre of these legal reforms. This definitely implies positive attempts that have been put forward by policy makers in deliberating policy formulations that aimed at ensuring equal treatment of all people in terms of gender, race, ethnicity and disability. However, significant challenges remain in putting to rest the conservative beliefs of patriarchal society.

The guiding principle in this scenario is the Communal Land Reform Act. Yet, the Act needs to be strengthened, both by its custodian Ministry of Land and Reform and by relevant stakeholders. This can be done through continuous engagement with the targeted audience which will eventually be the impetus for ensuring that the Act produces its envisioned outcomes. Literature in recent years has continuously indicated huge gender variations in communal land allocation, so immediate actions are required to address loopholes that undermine the effectiveness of the Act and its objectives. There is no need to re-invent the will; the will only requires amplification to give the intended results.

\section{Funding}

The author(s) received no financial support for the research, authorship, and/or publication of this article.

\section{ORCID iD}

Paulus Mwetulundila iD https://orcid.org/0000-0002-9024-9939

\section{References}

Adeniyi L (2010) Women farmer's and agriculture growth: Challenges and perspective for Africa face the economic crisis. Available at: http://ageconsearch.umn.edu/bitstream/97062/2/92.\%20Women\%20 labor\%20and\%20agriculture\%20growth.pdf (accessed 25 August 2020).

Akawa M (2014) The Gender Politics of the Namibia Liberation Struggle. Basel: Basler Africa Bibliographien.

Ambunda L and de Klerk S (2008) Women and custom in Namibia: A research overview. In: Ruppel O (eds) Women and Custom in Namibia: Cultural Practice Versus Gender Equality? Windhoek: Macmillan Education Namibia.

Constitution of the Republic of Namibia (1990) Windhoek: Government of the Republic. Windhoek.

De Klerk V (n.d.) Women's action for development: 15 years of experience with customary practice in rural Namibia. Available at: http://www.kas.de/upload/auslandshomepages/namibia/Women_Custom/klerk. pdf (accessed 10 September 2020).

Employment Equity Commission (2002) The employers' guidelines to the Affirmative Action (Employment) Act. Act No. 29 of 1998. Windhoek: EEC.

Employment Equity Commission (2015) Commission for Employment Equity Annual Report 2014-15. Windhoek: EEC.

Enyew BE and Mihrete AG (2018) Liberal feminism: Assessing its compatibility and applicability in Ethiopia context. International Journal of Sociology and Anthropology 10(6): 59-64

Food and Agriculture Organisation (2010) Gender \& land rights: Economic and social perspectives. Available at: http://www.fao.org/docrep/012/a1059e/a1059e00.pdf (accessed 12 September 2020).

Hubbard D (2018) Women and Communal Land: Issues to Consider. Windhoek: Legal Assistance Centre.

Hubbard D and Solomon C (n.d.) The women's movement in Namibia: History, constraints and potential. Available at: https://www.lac.org.na/projects/grap/Pdf/article95facesfeminism.pdf (accessed 2 May 2021).

Jauch H, Edwards L and Cupido B (2011) Inequality in Namibia. In: Jauch H and Muchena D (eds) Tearing Us Apart: Inequalities in South Africa. Johannesburg: Open Society Initiative for Southern Africa, pp. 181-255.

Kameri-Mbote P (2013) I want it and I want it now: Women and land in Africa. In: Al-Zubaidi L, Assubuji P and Luckscheiter J (eds) Women and Land Rights: Question of Access, Ownership and Land Control. Rome: 
IFAD. Available at: https://www.ifad.org/documents/10180/6eae64e8-875e-4a54-80f9-1d8100612331 (accessed 11 December 2020).

Likuwa K and Shiweda N (2017) Okaholo: Contract labour system and lessons for postcolonial Namibia. Mgbakoigba Journal of African Studies 6(2): 26-47.

Lorber J (n.d.) The variety of feminisms and their contribution to gender equality. Available at: http://diglib. bis.uni-oldenburg.de/pub/unireden/ur97/kap1.pdf (accessed 9 October 2020).

Malan J (2003) Guide to the Communal Land Reform Act: Act No. 5 of 2002. Windhoek: Land, Environment, and Development Project, Legal Assistance Centre and the Advocacy Unit, Namibia National Farmers Union.

Ministry of Gender Equality and Child Welfare (2010) National Gender Policy (2010-2020). Windhoek: Legal Assistance Centre and Namibia National Farmers Union.

Ministry of Land and Resettlement (1998) National Land Policy. Windhoek: Republic of Namibia.

Ministry of Land and Resettlement (n.d.) Promoting the communal land rights of vulnerable people. Available at: http://www.mcanamibia.org/files/files/40f_CLS\%202\%20Examples\%20of\%20printed $\% 20$ materials.pdf (accessed 21 August 2020).

Namibia Statistic Agency (2012) 2011 Population and Housing Census Report. Windhoek: NSA.

National Planning Commission (2012) Annual Economic Development Report. Windhoek: Office of the President.

National Planning Commission (2015) Poverty and deprivation in Namibia. Summary report, Republic of Namibia, National Planning Commission, Windhoek, Namibia.

Odeny M (2013) Improving access to land and strengthening women's land rights in Africa. Annual World Bank Conference on Land and Poverty. Available at: http://web.law.columbia.edu/sites/default/files/ microsites/gender-sexuality/odeny_improving_access_to_land_in_africa.pdf (accessed 19 September 2020).

Republic of Namibia (1995) Convention on the Elimination of All Forms of Discrimination against Women $(C E D A W)$. Windhoek: Department of Women Affairs, Office of the President.

Ruppel OL (2008) Women and Custom in Namibia: Cultural Practice Versus Gender Equality? Windhoeka: Macmillan Education Namibia.

Samkange W (2015) The liberal feminist theory: Assessing its applicability to education in general and early childhood development (ECD) in particular within the Zimbabwean context. Global Journal of Advancement 2(7): 1172-1178.

Shapi M, Nghitevelekwa R, Namupala N, et al. (2017) Baseline Study: Women's Land Use, Ownership and Land Rights in Ohangwena, Omusati, Oshana and Oshikoto Regions of Namibia. Windhoek: University of Namibia and Konrad Adenauer Foundation.

SIDA (n.d.) Quick guide to what and how; increasing women's access to land. Available at: https://www. oecd.org/dac/gender-development/47566053.pdf (accessed 17 October 2020).

Szapuová M (2006) Mill's liberal feminism: Its legacy and current criticism. Prolegomena 5(2): 179-191.

United Nations (2013) Realising women's right to land and other productive resources. New York and Geneva. Available at: https://www.ohchr.org/documents/publications/realizingwomensrightstoland.pdf (accessed 11 December 2020).

United Nations Development Programme (2015) Sustainable development goals. Available at: http://www. undp.org/content/dam/undp/library/corporate/brochure/SDGs_Booklet_Web_En.pdf

Werner W (2008) Protection for Women in Namibia's Communal Land Reform Act: Is it Working? Windhoek: Land, environmental and Development Project Gender Advocacy Project, Legal Assistance Centre.

\section{Author biography}

Mr Paulus Mwetulundila is a Researcher under the Gender Programme in the Social Science Division of the Multidisciplinary Research Centre (MRC) of the University of Namibia. He holds a MA in Gender and Development Studies. His primary research orientation centres on gender dynamics in the labour market as well as other social pathologies. His research interests are guided by Goal 5 of the Sustainable Development Goals (SDGs) which advocate for providing women and girls with equal access to education, health care, decent work, and representation in political and economic decision-making processes which will fuel sustainable economies and benefit societies and humanity at large. 